\title{
Performance Evaluation of Improved Forage Trees (Sesbania sesban) Cultivars for Animal feed and Nutritional Quality in Highlands of East Hararghe Zone, Oromia, Ethiopia
}

\author{
Wubshet Tesfaye* Tolera Fikadu Worku Bekuma Melese Furgasa \\ Oromia Agricultural Research Institute, Fedis Agricultural Research Center, Harar Ethiopia
}

\begin{abstract}
The experiment was conducted to evaluate the biomass yield and adaptability of five accession with one local check of Sesbania (Sesbania sesban) at Highland of Eastern Hararghe Zone in 2017/18 and 2018/19 G.C cropping season consecutive years on-FTC in Burka Jalala PA. The treatments evaluated were S.sesban 15019, S.sesban 10865, S.sesban 15036, S.sesban 10885, S.sesban 1238 and local check in a Randomized Complete Block Design (RCBD) with three replications. The biomass yield, plant height, stem weight, leaf to stem ratio (LSR) were taken at Annual. The analysis result indicated in Table $(1)$ showed that there was significant $(\mathrm{P}<0.05)$ variation among the accession in fresh leaf weight, fresh stem weight and percent of leaf to stem ratio. The results indicated that the maximum fresh leaf biomass yield of the accession S.sesban 1238 (7.91 ton ha $\left.{ }^{-1}\right)$, flowed by accessions S.sesban $10885\left(7.23\right.$ ton $\left.\mathrm{ha}^{-1}\right)$. The results showed that the maximum leaf to stem ratio were recorded under accession S.sesban 10865(28.67\%), S.sesban 15019(27.66\%) and S.sesban 1238(31.33\%). A significant variation $(\mathrm{p}<0.05)$ among the content of total ash and Acid detergent lignin. The maximum Acid detergent lignin obtained from S.sesban 15036(22.746\%), and the minimum Acid detergent lignin obtained from S.sesban 1238(14.875\%) and S.sesban 10885(14.874\%). It was concluded that the accessions S.sesban 1238 and S.sesban 10885 were found promising to be demonstrated under in the study areas and same agro-climatic conditions similar to study area.
\end{abstract}

Keywords: Forage Trees, Quality forage, Sesbania Sesban, Tree legumes

DOI: $10.7176 / \mathrm{FSQM} / 106-02$

Publication date:March $31^{\text {st }} 2021$

\section{Introduction}

Livestock and especially ruminants are an essential component of most of the agricultural production systems in sub-Saharan Africa. Also in Ethiopia Livestock is an integral component for most of the agricultural activities in the country. The livestock sector has a share of $12-16 \%$ of the total Gross Domestic Product (GDP), and 30-35\% of agricultural GDP (Ayele et al., 2002) And the majority of the population engage in subsistence level crop and livestock production (Nigussie, 2012), that is, mixed crop-livestock farming systems. Soil nutrient depletion and poor nutritive forage are the major causes of low crop and animal productivity in smallholders' farms especially in highland areas. As small-scale farmers cannot afford to use chemicals (Wakjira et al., 2011) and improved feeds in their agricultural production system, they resort to the use of natural ways of replenishing soil fertility and feeding livestock through agroforestry.

In the drier areas, the quantity of natural forages is often insufficient, whereas in the wetter areas, the feed supplies are usually ample but their protein and energy concentrations are low and they are poor quality. In both areas, feed shortages and nutrient deficiencies occur mainly in the dry season and similar to in the study area, livestock is greatly dependent on crop residues for feed and the farmers usually harvest fodder from thinned crop plants, weeds, and defoliated leaves (Kassa, 2003).

The increased utilization of leguminous and other tree and shrub species, fed as a high quality supplement to the low quality natural pastures and crop residues, has been recognized as one of the means of improving the forage supplies to ruminants in pastoral and crop-livestock systems. Although a wide range of shrubs and trees has been identified as suitable for feeding ruminant animals in the tropics (Topark-Ngarm, 1990) special attention has been given to leguminous species (Brewbaker, 1989). There are many reasons for the interest in the use of tree legumes in animal agroforestry. The possession of a long tap root enables the trees and shrubs to provide high quality green foliage even during most part of the dry season and once established, recycle plant nutrients from depths inaccessible to crops and pastures.

Leguminous tree species can improve soil fertility through nitrogen accumulation and help prevent soil erosion. As well as providing forage, they can also be an important source of fuelwood, a commodity that is often in short supply especially in the areas with high population density.

The perennial Sesbania species have considerable potential for use in agroforestry as they show a rapid early growth, grow under various ecological conditions and do not require difficult management procedures. Sesbania sesban found in areas with a semi-arid to sub humid climate, with a rainfall between $500-2000 \mathrm{~mm}$ per year. In the regions with low precipitation however, they occur primarily on poorly drained soils, which subjected to periodic waterlogging or flooding. Because of its good tolerance to low temperatures. Sesban is adapted to a wide 
variety of soil types, ranging from loose sandy soils to heavy clays. It has an excellent tolerance to waterlogging and flooding (Shelton, 1994). Therefore the activity done for the objective: To select and recommend high quantity yielding and adaptable sesbinia sesban accessions for small farmers households

\section{MATERIALS AND METHODS}

\subsection{Description of the Study Area}

The study was done on farm at East Hararghe Zone, Meta district, Buraka Jalala PA at FTC which are far from $419 \mathrm{~km}$ East of Addis Ababa which is 2130 m.a.s.l and annual rainfall 650- 900mm. Layout system was randomized complete block design (RCBD) three replication. Within $3 \times 3 \mathrm{~m}^{2}$ plot size. was used five (5) accession Sesbania sesban with one local check. A planting system was plated with seed rate of about three seed per polyethylene tube at the bed after the plat were well emerged within the spacing of $1 \mathrm{~m}$ between plants. Thinning was done two times at the bed and after transplanting without Fertilizer application

\section{Data Collection and Measurement}

Survival rate: count all plants after transplanted for a month on total plot size that was survived

Physical appearance: it was taken by simple visual observation of the planted materials interims of leafiness, and greenness

Plant height it was measured at 5 months interval after the plants survived and take average per annuals from the ground level to the tip from five randomly taken plants and was averaged on per plant basis by using $5 \mathrm{~m}$ scaled meter.

Dry leaf weight: it was taken after chopping into $5 \mathrm{~cm}-8 \mathrm{~cm}$ length of $200 \mathrm{~g}$ samples and then sun-dried until constant weight for dry biomass and then converted tone per hectare based

Dry stem weight: it was taken after chopping into $5 \mathrm{~cm}-8 \mathrm{~cm}$ length of $500 \mathrm{~g}$ samples and then sun-dried until constant weight and then converted tone per hectare based

Leaf to stem ratio: the ratio of dry leaf weight to dry stem weight multiply by $100 \%$

Chemical and quality parameters at Annual when the plant ripped well samples were taken randomly from three plants from the net plot for determination of dry biomass yield. The dry biomass weight of the sample taken after partial sun-dried of $150 \mathrm{~g}$ to determine the dry matters then the samples were oven-dried at $65{ }^{\circ} \mathrm{C}$ for 72 hours. The samples were analysis for Dry Matter (DM), Crude Protein (CP), fiber and Ash in Haramaya University nutritional laboratory.

Dry matter yield (DM): samples were prepared from the fresh samples and partial sun-dried then were ovendried to a constant temperature at $105{ }^{\circ} \mathrm{C}$ for $16 \mathrm{hrs}$ then re-weighted the dried samples. Laboratory dry matter $\%$ $($ Lab DM \% $)=\{(\mathrm{W} 6-\mathrm{W} 4) /(\mathrm{W} 5-\mathrm{W} 4)\}$ X 100\% Where: W4 = Empty weight of container in grams W5 = Initial weight of sample in grams W6 = Dry weight of sample and container in grams

Crude protein (CP): By micro-Kjeldahl method (AOAC, 1994) .The, crude protein content was determined by (Jackson, 1962).

Fiber: By Van Soest method (detergent Method) used to determine insoluble cell wall matrix such as; Neutral detergent fiber (NDF), Acid detergent fiber (ADF) and Acid detergent lignin (ADL) (Van Soest, 1967)

Ash: it was determined by igniting the dried sample in a muffle furnace at $500^{\circ} \mathrm{C}$ overnight, Cool in a desiccator, and take weigh.

\section{Statistical Analysis}

Data was analyzed using the Statistical Analysis Software to perform ANOVA (SAS 9.1) in a randomized complete block design. Means of all treatments were calculated and the difference was tested for significance using the least significant difference (LSD) test at $\mathrm{p}<0.05$ (Gomez and Gomez, 1984).

\section{RESULTS AND DISCUSSION}

\section{Growth parameters, yield components and yields}

Plant height was a good indicator of growth rate and adaptation of varieties to the environment. The mean performance of Plant heights of different sesbania sesban varieties at annual (1year) indicated that, the differences among the means of the varieties for the plant height trait were none significant among tested accession of Sesbania sesban. However, all result obtained from treatments of Sesbania sesban (in table 1) un average of $370.17 \mathrm{~cm}$; this showed that have high growth rate and this result lined with the result obtained in one years of plant heights of grand mean $373.29 \mathrm{~cm}$ reported by (Negasu and Gizahu, 2019).

Dry biomass yield they collected from leaves and soft tip buds that edible. Dry biomass yield was significantly different $(\mathrm{P}<0.05)$ among the treatments. The highest leaf dry biomass yield of $7.91 \mathrm{t} \mathrm{ha}^{-1}$ and $7.23 \mathrm{tha}^{-1} \mathrm{which}$ was obtained from S.sesban 1238 and S.sesban 10885 respectively followed by Sesbania sesban 15019 which recorded $6.21 \mathrm{t} \mathrm{ha}^{-1}$ whereas the minimum dry weight were recorded from accession of S.sesban 10865(4.64 $\mathrm{tha}^{-}$ 1) S.sesban $15036\left(5.51 \mathrm{t} \mathrm{ha}^{-1}\right)$ and local check $\left(5.23 \mathrm{t} \mathrm{ha}^{-1}\right)$. This result similar in range to the studies (Dutt et al., 1983; Gore SB \& Joshi RN, 1976; Galang et al., 1990), the yield of S. sesban have ranged from 4 to 12 tonnes dry matter/ha/year. However, the result obtained was disagreed with the result reported by Negasu and Gizahu, 2019, 
DZ- 96 produced maximum sun-dried dry matter yield (DMY) of 27.64 tha $^{-1}$, and while minimum sun-dried DMY of 9.88 tha $^{-1}$ was recorded from DZ-104 in two years the variation might be due to frequency of harvesting and seasonal variations

Dry stem yield of the mean that showed in table $(1)$ was significantly different $(\mathrm{P}<0.05)$ among the accession of Sesbania sesban, the maximum stem dry weight of $25.35 \mathrm{t} \mathrm{ha}^{-1}$ which was obtained from S.sesban 1238 , followed by S.sesban 1238, S.sesban 15019, Local Check and S.sesban 15036 which obtained(24.86,22.41, 22.36 and 21.40$)$ $\mathrm{t} \mathrm{ha}^{-1}$ respectively. Whereas the minimum stem dry weight was recorded from accession of S.sesban 10865(20.72 tha ${ }^{-1}$ )

Table 1: The Mean agronomic data, yield and yield component obtained from S.sesban

\begin{tabular}{ccccccc}
\hline Treatments & Survival rate $(\%)$ & $\begin{array}{c}\text { PHt } \\
(\mathrm{cm} / \text { year })\end{array}$ & $\begin{array}{c}\text { DLWt } \\
\left(\mathrm{t} \mathrm{ha}^{-1}\right)\end{array}$ & $\begin{array}{c}\text { DSWt } \\
\left(\mathrm{t} \mathrm{ha}^{-1}\right)\end{array}$ & $\begin{array}{c}\text { LSR } \\
(\%)\end{array}$ & $\begin{array}{c}\text { SY } \\
\mathrm{kg} / \mathrm{ha}\end{array}$ \\
\hline S.sesban 15019 & 100 & 354.67 & $6.21^{\mathrm{ab}}$ & $22.41^{\mathrm{ab}}$ & $27.66^{\mathrm{ab}}$ & 298.8 \\
S.sesban 10865 & 96.33 & 384.00 & $4.64^{\mathrm{b}}$ & $20.72^{\mathrm{b}}$ & $22.39^{\mathrm{b}}$ & 330.4 \\
S.sesban 15036 & 92.67 & 360.00 & $5.51^{\mathrm{b}}$ & $21.40^{\mathrm{ab}}$ & $25.75^{\mathrm{b}}$ & 317.2 \\
S.sesban 10885 & 92.67 & 370.67 & $7.23^{\mathrm{a}}$ & $25.35^{\mathrm{a}}$ & $28.67^{\mathrm{ab}}$ & 360.2 \\
S.sesban 1238 & 92.67 & 386.67 & $7.91^{\mathrm{a}}$ & $24.86^{\mathrm{ab}}$ & $31.33^{\mathrm{a}}$ & 380.9 \\
Local Check & 95.33 & 365.00 & $5.23^{\mathrm{b}}$ & $22.36^{\mathrm{ab}}$ & $23.39^{\mathrm{b}}$ & 319.1 \\
\hline Grand Mean & 94.95 & 370.17 & 6.39 & 22.95 & 26.53 & 361.82 \\
CV(\%) & 8.19 & 12.26 & 19.37 & 31.71 & 29.21 & 18.26 \\
LSD(0.05) & NS & NS & 2.4 & 4.21 & 5.65 & NS \\
\hline
\end{tabular}

Means with the same letter in the same column are not significantly $(\mathrm{p}<0.05)$ different. $\mathrm{PH}=$ plant height, $\mathrm{FLW}=$ fresh leaf weight, $\mathrm{FSW}=$ fresh stem weight, $\mathrm{DLWt}=$ dry leaf weight, $\mathrm{DSW}=$ dry stem weight and $\mathrm{LRS}=\mathrm{leaf}$ to stem ratio, $\mathrm{SY}=$ seed yield

Leaf to stem ratio of dry biomass it was observed and the mean indicated in table (1), was a significantly different $(\mathrm{P}<0.05)$ among the treatments. The highest percent of leaf to stem dry yield of $31.67 \%$, which was obtained from S.sesban 1238, followed by S.sesban 10885 and S.sesban 15019 were recorded $28.67 \%$ and $27.66 \%$ respectively. Whereas the minimum leaf to stem ratio obtained from accession of S.sesban 10865 (22.39\%), S.sesban $15036(25.75 \%)$ and 1 ocal check (23.39\%)

However, among the parameters that obtained from S.sesban accession like survival rate, seed yield have no a significant deferent $(\mathrm{p}>0.05)$ among the accession of Sesbania sesban

Physical appearance, disease and pests it was taken by simple visual observation of Sesbania accession well performed, greens and very good ground covers through the years and not observed any disease during field experiment was implemented
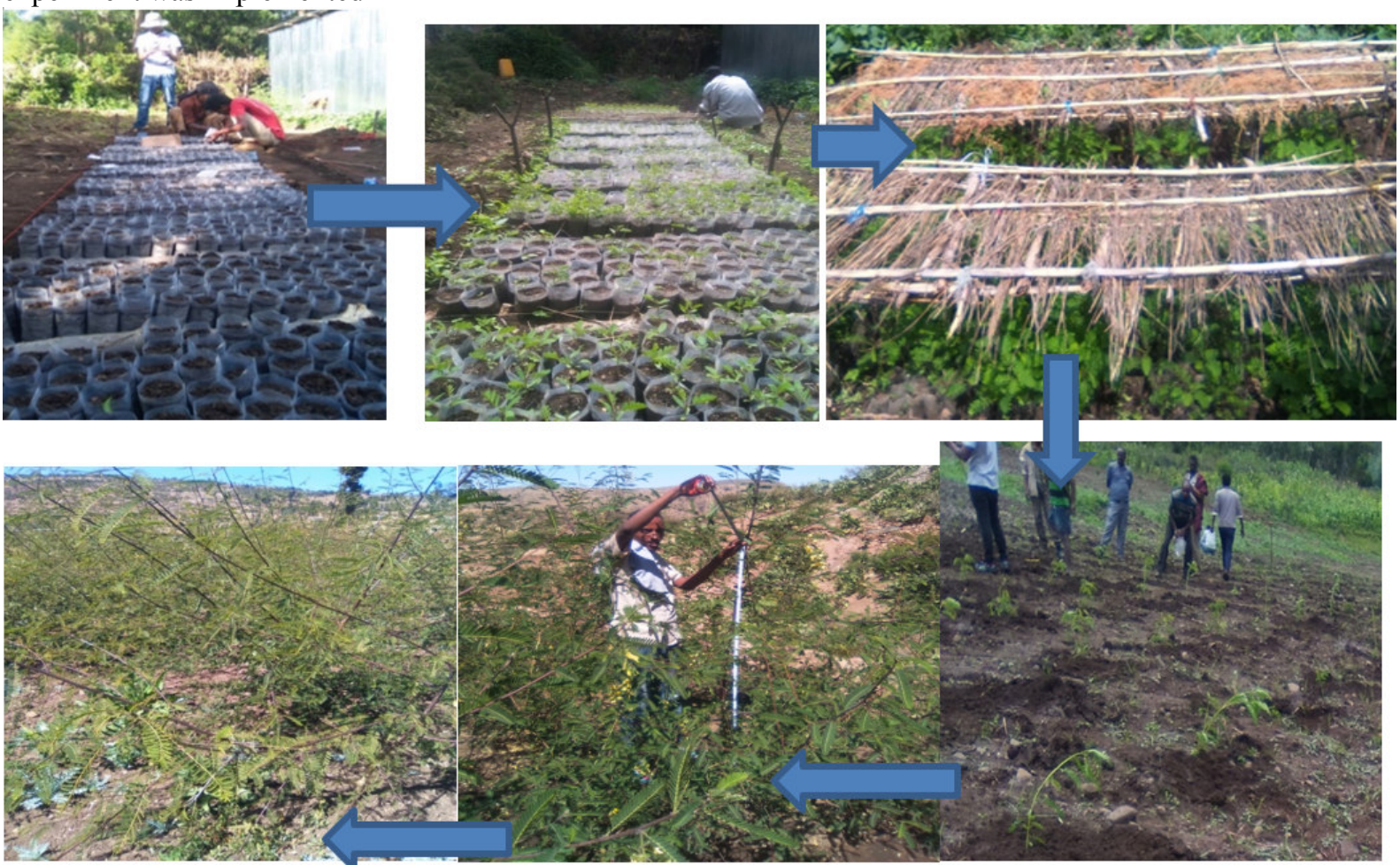

Figurs 1 . The figures that showed during activity was implemented 


\section{Chemical and Nutritional Quality Parameters of Sesbania sesban in the Highland of East Hararghe}

There was a significant difference $(\mathrm{p}<0.05)$ among the chemical composition content (Ash and ADF). However, none significant of DM, CP and NDF) of Sesbania sesban accession that showed in (Table 2). The Ash showed that a significant different $(\mathrm{p}<0.05)$ among the treatments of Sesbania sesban accession. The maximum Ash recorded by S.sesban 10865 and S.sesban 1238 [(15.89 and 15.88\%) respectively and followed by S.sesban 15019(15.095\%). Whereas the lowest contents of Ash recorded under S.sesban 15036, S.sesban 10885 and Local Check $(14.81 \%, 15.062 \%$ and $15.021 \%)$ respectively.

The crude protein content was not significantly different $(\mathrm{P}>0.05)$ obtained from treatments of Sesbania sesban. In general, CP that obtained from tested sesban accession were classified under good quality animal feeds according to General Forage Quality Standards for Livestock Diets classification, $>19 \%$ prime(the best quality feeds), QS(1)17-19\%, QS(2)14-16\%, QS(3) 11-14\%, QS(4) 8-10\% and QS(5) < 8\% of CP indicated that the lowest quality.

Table 2. The mean of nutritional quality parameters of Sesbania sesban accession

\begin{tabular}{ccccccc}
\hline Treatments & $\begin{array}{c}\text { DM } \\
(\%)\end{array}$ & $\begin{array}{c}\text { ASH } \\
(\%)\end{array}$ & $\begin{array}{c}\text { CP } \\
(\%)\end{array}$ & $\begin{array}{c}\text { NDF } \\
(\%)\end{array}$ & $\begin{array}{c}\text { ADF } \\
(\%)\end{array}$ & $\begin{array}{c}\text { ADL } \\
(\%)\end{array}$ \\
\hline S.sesban 15019 & 85.221 & $15.095^{\mathrm{ab}}$ & 18.371 & 37.324 & 16.759 & $15.87^{\mathrm{b}}$ \\
S.sesban 10865 & 86.762 & $15.89^{\mathrm{a}}$ & 18.237 & 37.621 & 17.178 & $22.246^{\mathrm{a}}$ \\
S.sesban 15036 & 85.291 & $14.81^{\mathrm{b}}$ & 18.187 & 36.824 & 16.259 & $22.746^{\mathrm{a}}$ \\
S.sesban 10885 & 86.853 & $15.062^{\mathrm{b}}$ & 18.385 & 37.136 & 14.643 & $14.874^{\mathrm{b}}$ \\
& & & & & \\
S.sesban 1238 & 86.259 & $15.889^{\mathrm{a}}$ & 18.585 & 36.812 & 16.678 & $14.875^{\mathrm{b}}$ \\
Local Check & 86.721 & $15.012^{\mathrm{b}}$ & 18.287 & 37.216 & 16.187 & $18.264^{\mathrm{ab}}$ \\
\hline Grand Mean & 86.077 & 15.349 & 18.353 & 36.987 & 16.304 & 18.121 \\
CV(\%) & 1.24 & 2.13 & 3.54 & 3.56 & 12.45 & 9.71 \\
LSD(0.05) & $\mathrm{NS}$ & 0.284 & $\mathrm{NS}$ & $\mathrm{NS}$ & $\mathrm{NS}$ & 1.523 \\
\hline
\end{tabular}

Means within the same column followed by the same letter or by no letters of each factor do not differ significantly at $5 \%$ probability level. $\mathrm{DM}=$ dry matter, $\mathrm{CP}=$ rude protein, $\mathrm{NDF}=$ neutral detergent fiber; $\mathrm{ADF}=$ acid detergent fiber; $\mathrm{NS}=$ none significant. $\mathrm{LSD}=$ Least significant difference; $\mathrm{CV}=$ coefficient of variance.

The fiber fractions; [acid detergent fiber (ADF), neutral detergent fiber (NDF) and acid detergent lignin $(\mathrm{ADL})]$; the ADL content was significantly different $(\mathrm{p}<0.05)$ in the dry matter obtained from the forage sesbania sesban. The maximum ADL showed in table 2 were recorded from S.sesban 10865 and S.sesban 15036 . Whereas the minimum ADL of Sesbania sesban was obtained of S.sesban 10885, S.sesban 1238 (14.874 and 14.875) respectively. In general, this result indicates that the tested Sesbania sesban accession have high contents of CP and low contents of fiber fraction (NDF, ADF and ADL) so that Sesbania sesnan used as concentrate animal feed resources in the study area.

\section{Conclusion and Recommendation}

The performance of Sesbania sesban was tested in the Highland of east Hararghe zone of Oromia regional state. The result showed that significant $(\mathrm{P}<0.05)$ variation among the accession of Sesbania, among the parameters of; Dry leaf weight, fresh stem weight and percent of leaf to stem ratio. Among the tested fodder tree (Sesbania sesban) S.sesban 1238 and S.sesban 10885 Accession have greater performances in terms of their high dry Biomass yield, leaf to stem ratio and better agronomic parameters and quality forage. Therefore it was concluded that the accessions S.sesban 1238 and S.sesban 10885 promising to be demonstrated in the study area and under the same agro-climatic conditions and better to popularize for their livestock mix with poor quality (crop residues) as feed resources to enhance animal products

\section{References}

Ayele, S., Assegid, W., Jabbar, M.A., Ahmed, M.M. and Belachew, H., 2002. Livestock marketing in Ethiopia. A review of structure, performance and development initiatives. Socio-economics and Policy Research Working Paper 52. ILRI, Nairobi, Kenya

Brewbaker, J.L., 1989. Nitrogen fixing trees for fodder and browse in Africa. In Kang, B.T. and Reynolds, L. (Eds.) Alley Farming in the Humid and Subhumid Tropics. Proceedings of an international workshop held at Ibadan, Nigeria, 10-14March 1986. pp.55-70. International Development Research Centre, Ottawa, Canada.

Dutt AK, Pathania U, Kumar V. 1983. Growth of Sesbania sesban. Nitrogen Fixing Tree Res. Rep.; 1:5-6

Kassa, Belay H. 2003. Livestock and livelihood security in the Highlands of Ethiopia. Implication for Research and Development. PhD Thesis, Swedish University of Agricultural Sciences, Upsala, Sweden.

Negasu Gamachu, and Gizahu Wekgari. (2019). "ADAPTATION STUDY OF IMPROVED FODDER TREE (SESBANIA SESBAN (L.) MERRIL) AT HARO SABU, KELEM WOLLEGA, OROMIA, ETHIOPIA.” 
International Journal of Research - Granthaalayah, 7(8), 212-219. https://doi.org/10.5281/zenodo.3381306.

Nigussie Z , 2012. Contribution of White Lupin (Lupinus albus L.) for food security in North Western Ethiopia:

A Review. Asian J. Plant Sci. 11(5):200-205. doi: 10.3923/ajps. 2012.200.205

Galang MC, Gutteridge RC, Shelton HM. The effect of cutting height and frequency on the productivity of Sesbania sesban var. Nubica in a sub-tropical environment. Nitrogen Fixing Tree Res. Rep. 1990; 8:161-164.

Gore SB, Joshi RN. Effect of fertilizer and frequency of cutting on the extraction of protein from Sesbania. Indian J Agron. 1976; 21:39-42.

Topark-Ngarm, A., 1990. Shrubs and fodder trees in farming systems in Asia. In Devendra, C. (Ed.) Shrubs and Tree Fodders for Farm Animals. Proceedings of a workshop in Denpasar, Indonesia, 24-29 July 1989. pp1221. International Development and Research Centre, Ottawa, Canada.

Wakjira M, Berecha G, Bulti B (2011). Phytotoxic effects of multi-purpose tree species on germination and growth of Parthenium hysterophorus L. Int. J. Agric. Res., 6(2):149-162. doi: 10.3923/ijar.2011.149.162

Winrock, 1992. Assessment of Animal Agriculture in Sub-Saharan Africa. Winrock International Institute for Agricultural Development, Arkansas, USA. 